\title{
1 Stable isotopes suggest fine-scale sexual segregation in an isolated, endangered
}

sperm whale population

3 Enrico Pirotta ${ }^{1,2 *}$, Morgana Vighi ${ }^{3}$, José María Brotons ${ }^{4}$, Eileen Dillane ${ }^{2}$, Margalida Cerdà ${ }^{4}$, Luke Rendell $^{5}$

5

$6{ }^{1}$ Department of Mathematics and Statistics, Washington State University, 98686 Vancouver, WA, USA

$8{ }^{2}$ School of Biological, Earth and Environmental Sciences, University College Cork, T23 N73K Cork, Ireland

${ }^{3}$ Department of Evolutionary Biology, Ecology and Environmental Sciences, IRBio, Faculty of Biology, University of Barcelona, 08028 Barcelona, Spain

17 Running page head: Fine-scale sexual segregation in sperm whales.

*Corresponding author: Department of Mathematics and Statistics, Washington State University, 14204 NE Salmon Creek Avenue, Vancouver, WA 98686, USA; enrico.pirotta@wsu.edu 


\section{Abstract}

2 Sexual segregation is common among marine mammals, leading to intraspecific differences in

3 diet, diving behaviour, home range size, and even latitudinal distribution and migratory patterns.

4 Sperm whales (Physeter macrocephalus) present one of the most extreme examples of sexual

5 dimorphism both in size and social structure, with males and females segregating at different

6 latitudes across most of their range, but the underlying ecological drivers remain unclear.

$7 \quad$ Studying fine-scale dietary and habitat differences where the sexes occur in sympatry could

8 therefore provide insights into the mechanisms underpinning their large-scale segregation. In this

9 study, we analysed the carbon and nitrogen stable isotope values in the skin of males and females

10 from an isolated, endangered population inhabiting the Mediterranean Sea, sampled in a region

11 where the sexes occur and feed regularly in the summer months but show subtle differences in

12 habitat preference. We found marked differences in both carbon and nitrogen isotopic values

13 between the sexes, indicating that they could be targeting prey items in different trophic levels

14 and habitats. Combined with the evidence from habitat modelling studies, our results suggest that

15 female and male sperm whales segregate even in the latitudinally restricted Mediterranean

16 population, at a much smaller scale. This sympatric, fine-scale sexual segregation suggests that

17 reduction of competition may have been a key factor in the evolution of the species' social

18 structure and large-scale latitudinal segregation.

20 Keywords: dietary differences, sexual segregation, dimorphism, sperm whale, Mediterranean 21 Sea. 
2 Sexual segregation is a widespread phenomenon in animal ecology (Ruckstuhl 2007, Main

3 2008), with important implications for both the theoretical understanding of population and

4 ecosystem dynamics, and the design of effective conservation efforts (Wearmouth \& Sims 2008).

5 Among marine mammals, key top-down drivers of marine community structure (Bowen 1997,

6 Williams et al. 2004, Baum \& Worm 2009), social and habitat segregation can result in sex

7 differences in diet, diving behaviour, home range size, and even latitudinal distribution and

8 migratory patterns (Wearmouth \& Sims 2008). Such variation has been described in many

9 pinnipeds (e.g., Lesage et al. 2001, Breed et al. 2006, Tucker et al. 2007, Bailleul et al. 2010,

10 Kernaléguen et al. 2016) and some cetaceans (e.g., Marcoux et al. 2012, Gavrilchuk et al. 2014),

11 particularly in species that show a high degree of body size dimorphism. Reproductive status,

12 energetic requirements and intersexual competition have been proposed as potential explanations

13 for these differences (Wearmouth \& Sims 2008), but the proximate or ultimate mechanisms

14 driving the evolution of sexual segregation are still debated (Ruckstuhl 2007).

15 The sperm whale (Physeter macrocephalus) is highly sexually dimorphic, with males being

16 substantially larger than females. These morphological differences are thought to be largely due

17 to sexual selection (Cranford 1999, Whitehead 2003). In most studied populations, social

18 structure and broad-scale habitat use is also strikingly different between the sexes: females and

19 young form long-lasting social units at latitudes approximately $<40^{\circ}$, while males become

20 increasingly solitary with age and simultaneously move to increasingly higher latitudes

21 (Whitehead 2003). The species is characterised by a diet mainly composed of mesopelagic

22 cephalopods (Kawakami 1980, Clarke et al. 1993, Santos et al. 1999, Roberts 2003, Foskolos et

23 al. 2020). 
1 Analyses of stomach contents from stranded individuals have suggested some differences in diet

2 between the sexes, with males targeting larger and deeper prey items and consuming additional

3 non-cephalopod prey at high latitudes (e.g., Clarke et al. 1993, Best 1999, Flinn et al. 2002,

4 Evans \& Hindell 2004, Teloni et al. 2008). In addition to the latitudinal separation when not

5 breeding, males and females also appear to show subtly different habitat preference in regions

6 and periods where they co-occur (e.g., Best 1999, Gregr \& Trites 2011, Pirotta et al. 2011, 2020).

7 Females tend to have higher feeding success in these areas, leading to the hypothesis that they

8 outcompete males for the highest quality habitat (Clarke et al. 1988, Best 1999, Whitehead

9 2003). Together with reproductive requirements (e.g., the need to care for young individuals),

10 these dietary and habitat differences could thus provide insights into the mechanisms underlying

11 the evolution of sperm whale social structure, size dimorphism and ecology.

12 Stable isotope analysis is a powerful tool to investigate variation in diet among individuals or

13 groups of individuals (Post 2002), but limited by a low taxonomic resolution (Nielsen et al.

14 2018). Using this technique on sperm whale skin samples, Ruiz-Cooley et al. (2004) detected

15 dietary differences between males and females in the Gulf of California. However, given isotope

16 turnover rates, the authors suggested these differences could reflect the diet of adult males in

17 high-latitude feeding grounds or any period of fasting during their migration to lower latitudes,

18 i.e. their large-scale latitudinal segregation, rather than sympatric differences in the area where

19 they co-occurred with social units and were sampled. Such suggestions are consistent with the

20 ontogenetic changes found in other studies (Mendes et al. 2007b). Similarly, Borrell et al. (2013)

21 found sexual differences in isotopic values in sperm whale dentine samples from the Eastern

22 North Atlantic, which they attributed to large-scale segregation and population structuring. 
1 Therefore, it remains to be confirmed whether males and females vary in their diet when they co-

2 occur at lower latitudes.

3 A small population of sperm whales inhabits the Mediterranean Sea and is classified as

4 'Endangered' in the IUCN Red List (Rendell \& Frantzis 2016). Genetic and photo-identification

5 studies have shown that the population is isolated from the North-east Atlantic (Drouot et al.

6 2004a, Engelhaupt et al. 2009, Carpinelli et al. 2014, Alexander et al. 2016). Relative to sperm

7 whales in other oceans, males in this population are thought to be generally smaller (Drouot et al.

8 2004b, Frantzis et al. 2014), possibly implying smaller differences in energy requirements and

9 diving capabilities compared to females. Analysis of stomach contents of stranded Mediterranean

10 individuals suggested a diet dominated by cephalopods of the genera Histioteuthis and

11 Octopoteuthis (Roberts 2003, Foskolos et al. 2020).

12 Within this enclosed basin, the potential for the large-scale latitudinal segregation between sexes

13 observed in other oceans is much reduced due to geographical constraints. Information on

14 movements within the Mediterranean is limited, but photo-identification studies in the western

15 basin have demonstrated that individuals can move between the area of the Ligurian Sea and

16 Gulf of Lions, the Strait of Gibraltar, and the waters around the Balearic archipelago (Spain),

17 covering distances up to $~ 1,600 \mathrm{~km}$ (Drouot-Dulau \& Gannier 2007, Carpinelli et al. 2014,

18 Rendell et al. 2014). The Balearic archipelago is an area where both female groups and singleton

19 males are regularly encountered during summer monitoring surveys (Pirotta et al. 2011, 2020,

20 Rendell et al. 2014). Both sexes are observed consistently engaging in long dives while actively

21 searching for prey (as suggested by their echolocation activity), indicating they are feeding in

22 this area in the summer months. At least in this season, the sexes thus appear to be sympatric at

23 the regional scale, but there is evidence of varying habitat preferences on finer spatial scales of 
1 approximately $10 \mathrm{~km}$ (Pirotta et al. 2011, 2020, Jones et al. 2016). Specifically, groups are

2 encountered in deeper, warmer waters characterised by lower sea level anomaly compared to

3 singletons, suggesting that the sexes may be segregating at these smaller scales (Pirotta et al.

4 2020). Therefore, the analysis of stable isotopes in this area could help our understanding of fine-

5 scale sexual segregation in the species.

6 While previous studies have measured stable isotope values in samples from Mediterranean

7 sperm whales (Mazzariol et al. 2011, Praca et al. 2011, Pinzone et al. 2015), none have explicitly

8 assessed isotopic differences between sexes. Here, we analysed the stable isotope values in the

9 skin of male and female sperm whales sampled around the Balearic Islands, with the aim of

10 exploring intraspecific differences in diet in a season where the sexes are encountered within the

11 same region. These differences could indicate the occurrence of sexual segregation in a low-

12 latitude area where the sexes are broadly sympatric. Dietary differences between males and

13 females could reflect a differential use of the water column or of portions of the distribution

14 range. In turn, this would affect their exposure to the human activities that threaten the

15 population's survival (Rendell \& Frantzis 2016), thus highlighting the potential need for sex-

16 specific conservation strategies.

17

\section{MATERIALS \& METHODS}

\subsection{Data collection}

Between May and September 2019, sperm whales were approached to collect biopsy samples

21 while at the surface between foraging dives using a 12-m auxiliary powered sailing yacht. We

22 distinguished between encounters with single individuals and encounters with groups, defined as 
1 individuals (often including young animals) engaging in direct interaction or 'moving together in

2 a coordinated fashion' (Whitehead, 2003).

3 Biopsies were performed using a $150 \mathrm{lb}$ pull crossbow (manufactured by Barnett International)

4 and arrows with stainless steel sampling heads of $0.5 \mathrm{~cm}$ diameter and $2.5 \mathrm{~cm}$ length (Ceta-Dart,

5 Denmark). Arrows were shot from a distance $<15 \mathrm{~m}$, aiming for the mid-lateral region of the

6 body, below the dorsal fin.

7 We successfully collected biopsy samples from 20 individual sperm whales (Fig. 1A). Most

8 individuals (90\%) showed some short-term behavioural reaction to sampling, including startle,

9 defecation, shallow diving, and horizontal avoidance. All sampled individuals were subsequently

10 identified using photographs of their dorsal and caudal fin to avoid repeated sampling.

11 After retrieving the arrow, the sample was removed from the sampling head and divided in two

12 parts longitudinally. One half was directly frozen onboard in an electric freezer (for stable

13 isotope analysis), while the other half was placed in ethanol (for genetic sex determination). The

14 sampling heads were then sterilized using bleach and rinsed with $90 \%$ alcohol for subsequent

15 reuse.

\subsection{Laboratory analyses}

17 All stable isotope analyses were undertaken at the Centres Científics i Tecnològics of the

18 University of Barcelona (CCiT-UB). Subsamples of skin were defrosted, minced with scalpel and

19 scissors, and dried at $60^{\circ} \mathrm{C}$ for $48 \mathrm{~h}$. Dried samples were treated with a chloroform-methanol (2:1)

20 solution to extract lipids (Bligh \& Dyer 1959). Lipid extraction can alter $\delta^{15} \mathrm{~N}$ values (Logan \&

21 Lutcavage 2008, Smith et al. 2020), but was required to prevent the confounding effect of lipids

22 on isotopic values, in the absence of tissue- and species-specific lipid-normalization models 
1 (Lesage et al. 2010). Given that the aim of the study was to assess differences between the sexes,

this technique was deemed appropriate, since the consequences of lipid extraction are primarily relevant when comparing isotopic values with putative prey or samples from other laboratories. Subsequently, samples were dried at $60{ }^{\circ} \mathrm{C}$ for $48 \mathrm{~h}$. The lipid content was determined as the difference in sample weight before and after the lipid-extraction treatment. Approximately $0.3 \mathrm{mg}$ of each sample was weighed in tin capsules, automatically loaded, and combusted at $1,000{ }^{\circ} \mathrm{C}$ for analysis in a continuous flow isotope ratio mass spectrometer (Flash 1112 IRMS Delta C Series EA Thermo Finnigan, Bremen, Germany). Standards for $\delta^{13} \mathrm{C}$ and $\delta^{15} \mathrm{~N}$ were the Vienna Pee Dee Belemnite limestone (V-PDB) and the atmospheric nitrogen, respectively. International isotope secondary standards of known ${ }^{13} \mathrm{C} /{ }^{12} \mathrm{C}$ and ${ }^{15} \mathrm{~N} /{ }^{14} \mathrm{~N}$ ratios in relation to $\mathrm{V}$-PDB and atmospheric nitrogen, respectively, were used for calibration of $\delta^{13} \mathrm{C}$ and $\delta^{15} \mathrm{~N}$, namely: polyethylene (IAEA $\mathrm{CH} 7 ; \delta^{13} \mathrm{C}=-31.8 \%$ ), ammonium sulphate (IAEA $\mathrm{N} 1 ; \delta^{15} \mathrm{~N}=+0.4 \%$ o and IAEA $\mathrm{N} 2 ; \delta^{15} \mathrm{~N}=$ $+20.3 \%$ ), L-glutamic acid (USGS $40 ; \delta^{13} \mathrm{C}=-26.2 \% ; \delta^{15} \mathrm{~N}=-4.6 \%$;) and caffeine (IAEA 600; $\delta^{15} \mathrm{~N}=1,0 \% ; ; \delta^{13} \mathrm{C}=-27,7 \%$ ). The reference materials used are distributed by the International Atomic Energy Agency (IAEA) and were selected based on previous calibration experiments to ensure an optimum range of reference values. Calibration precision based on replicate measurements of the internal laboratory standards was $0.23 \pm 0.15 \%$ for $\delta^{13} \mathrm{C}$ and $0.19 \pm 0.11 \%$ o for $\delta^{15} \mathrm{~N}$. Results were expressed as per mil (\%o) following the delta $(\delta)$ notation, according to the equation: $\delta^{13} \mathrm{C}$ or $\delta^{15} \mathrm{~N}(\% 0)=\left[\left(\frac{R_{\text {sample }}}{R_{\text {standard }}}\right)-1\right] \cdot 10^{3}$, where $R$ is the heavy-to-light isotope $\operatorname{ratio}\left({ }^{15} \mathrm{~N} /{ }^{14} \mathrm{~N} ;{ }^{13} \mathrm{C} /{ }^{12} \mathrm{C}\right)$.

The determination of the sex of sampled individuals was conducted at the DNA/Molecular Genetics laboratory in the School of Biological, Earth and Environmental Sciences of University College Cork. Genomic DNA was extracted from each ethanol-preserved skin subsample using 
1 the Qiagen DNeasy® Blood and Tissue kit. Sex determination was carried out following Rosel

2 (2003).

$3 \quad 2.3$ Statistical analysis

4 Differences in $\delta^{13} \mathrm{C}$ and $\delta^{15} \mathrm{~N}$ values between males and females were tested using Gaussian linear

5 models; assumptions of residual normality and homogeneity of variance across sexes were

6 assessed using Shapiro-Wilks and Levene's tests, respectively. Some individuals were sampled as

7 part of the same group, which could imply that their dietary choices were not independent.

8 Therefore, we also refitted the models using a working independence correlation structure in a

9 Generalised Estimating Equations (GEE) framework (Hardin \& Hilbe 2003), where group identity

10 was used as the blocking factor. A sandwich variance estimator provided robust estimates of

11 precision accounting for the observed degree of autocorrelation within each block (Hardin \& Hilbe

12 2003), which were used in a Wald's test to assess whether differences between the sexes were

13 significant.

14 Frequentist standard ellipses (containing approximately $40 \%$ of the data) corrected for small

15 sample sizes (SEAC) were generated using package SIBER (Jackson et al. 2011) for R v3.6.0 (R

16 Core Team 2019). The robust Bayesian framework implemented in SIBER was also used to

17 estimate Bayesian standard ellipses $\left(\mathrm{SEA}_{\mathrm{B}}\right)$ and compare isotopic niche widths for the two sexes.

18 An uninformative inverse Wishart prior with 2 degrees of freedom and scale matrix $\left[\begin{array}{ll}1 & 0 \\ 0 & 1\end{array}\right]$ was

19 used for the covariance matrix, while uninformative Gaussian priors with mean $=0$ and precision

$20=0.001$ were used for the means (package defaults). Markov chain Monte Carlo algorithms were

21 run for $10^{6}$ iterations (discarding the first 1,000 iterations as burn-in). 
1

2 Genetic sexing indicated that seven sampled individuals were females, while the remaining

3 thirteen were males. Among sampled males, seven were recorded as singletons. Additionally,

4 three males were sampled from a group of seven, even though they were not visibly smaller than

5 other sampled males. The remaining three males were sampled while grouped together (without

6 other individuals), and included a smaller, probably younger individual observed closely

7 interacting with the boat and engaging in aerial displays. All the sampled females were part of

8 four separate groups.

$9 \quad$ Male $\delta^{15} \mathrm{~N}$ values ranged between 11.4 and 13.5\% (mean \pm SD: $\left.12.4 \pm 0.6\right)$, while female $\delta^{15} \mathrm{~N}$ 10 values ranged between 10.8 and $11.6 \%$ (mean $\pm \mathrm{SD}: 11.2 \pm 0.3) ; \delta^{13} \mathrm{C}$ values ranged between -

1118.4 and $-17.6 \%$ for males (mean \pm SD: $-18.0 \pm 0.2$ ), and between -18.6 and $-18.2 \%$ for

12 females (mean \pm SD: $-18.4 \pm 0.1$ ). The $\mathrm{C}: \mathrm{N}$ ratio in the lipid-extracted skin samples fell between

$13 \quad 3.1$ and $3.6 \%$, confirming that the lipid extraction process was effective and did not affect $\delta^{13} \mathrm{C}$

14 values (Ryan et al. 2012, Giménez et al. 2017).

15

16

17

18

19

20

21

22

SEA $_{C}$ for males and females did not overlap (Fig. 1B). Using 10,000 posterior draws of SEA , a very small overlap was confirmed $($ mean $=3.6 \%$; median $=0 \%)$. Stable isotope values for one sampled male differed markedly from other male $\delta^{15} \mathrm{~N}$ and $\delta^{13} \mathrm{C}$ values, falling within the female convex hull; this was the smaller individual sampled in a group of three. The Gaussian models highlighted that males had significantly higher $\delta^{15} \mathrm{~N}$ (coefficient estimate $=1.22$, standard error $=$ $0.23, t$-value $=5.23, \mathrm{p}<0.001)$ and $\delta^{13} \mathrm{C}($ coefficient estimate $=0.45$, standard error $=0.09, t$ value $=5.00, \mathrm{p}<0.001)$; the tests on model residuals suggested that the assumptions of normality and homogeneity of variance between groups were met. The GEE analysis suggested 
1 that these differences remained significant even after accounting for any correlation within social

2 groups $\left(\delta^{15} \mathrm{~N}: \chi^{2}=49.3, \mathrm{p}<0.001 ; \delta^{13} \mathrm{C}: \chi^{2}=27.5, \mathrm{p}<0.001\right)$.

3 Males' isotopic niche width had a 98\% probability of being larger than females' (ratio of the

4 posterior modes $=3.1$; Fig. 2). However, the probability of a sex difference in niche width

5 dropped substantially when excluding the smaller male with female-like isotope values (mode

6 ratio $=1.6 ; 79 \%$ probability of males' niche width being larger than females'; Fig. 2).

\section{DISCUSSION}

9 We detected clear differences in the $\delta^{15} \mathrm{~N}$ and, to a smaller extent, $\delta^{13} \mathrm{C}$ values of male and

10 female sperm whales sampled around the Balearic archipelago (Spain), where both sexes are

11 observed to feed regularly in the summer months. Isotopic differences between the sexes in other

12 ocean basins have been attributed to large-scale latitudinal segregation (Ruiz-Cooley et al. 2004,

13 Borrell et al. 2013). Males in the Mediterranean cannot undergo such an extended latitudinal

14 migration, but photo-identification evidence suggests they do move between the Balearics, the

15 north-western basin, and the Strait of Gibraltar (Drouot-Dulau \& Gannier 2007, Carpinelli et al.

16 2014). Females could also move (Rendell et al. 2014), although social groups are believed to be

17 more philopatric (Whitehead 2003). If individuals experience different isotopic baselines during

18 movements within the western basin, this could be reflected in their isotopic values (Graham et

19 al. 2010). However, given the short isotope turnover rates in odontocete skin (less than 1-1.5

20 month; e.g., Browning et al. 2014, Giménez et al. 2016), the fact that samples were collected

21 over a period of four months, and the within-sex consistency in our sample, stable isotope values

22 are likely indicative of differences in the prey targeted by males and females when they are 
1 occurring around the Balearic archipelago. Despite the preliminary nature of our study, these

2 results could therefore support the existence of marked, intraspecific dietary differences in sperm

3 whales belonging to this isolated, endangered population.

$4 \quad$ Higher $\delta^{15} \mathrm{~N}$ in males could indicate that they were feeding either on prey species at a higher

5 trophic level, or on larger individuals of the same species (Hooker et al. 2001, Ruiz-Cooley et al.

6 2004, Newsome et al. 2010), in line with the limited available evidence from stomach content

7 analysis in the Mediterranean (I. Foskolos, personal communication) and other areas (Best 1999,

8 Evans \& Hindell 2004), and from stable isotopes in teeth (Mendes et al. 2007a, Borrell et al.

9 2013). The difference in $\delta^{13} \mathrm{C}$ was small compared to the corresponding analytical precision

$10(0.23 \pm 0.15 \%)$. However, as supported by the results of the statistical analysis and the separate

11 clustering of male and female samples along this axis (Fig. 1B), the variability within each group

12 was smaller than that between groups, suggesting that differences in $\delta^{13} \mathrm{C}$ could be ecologically

13 relevant. If confirmed, this could indicate that the sexes were occupying habitats that differed at

14 a fine scale, in accordance with visual and acoustic surveys in this and other low-latitude areas

15 indicating that females are generally observed further offshore or in waters with distinct oceanographic characteristics (Best 1999, Gregr \& Trites 2011, Pirotta et al. 2020).

17 A qualitative comparison with other published sperm whale isotopic values in the Mediterranean (Mazzariol et al. 2011, Praca et al. 2011, Pinzone et al. 2015) suggests some variation among

19 studies (Fig. 3). Female sperm whales in our study also appear to have lower $\delta^{13} \mathrm{C}$ than other

20 Mediterranean deep-diving odontocetes, but comparable $\delta^{15} \mathrm{~N}$, whereas males are characterised

21 by higher $\delta^{15} \mathrm{~N}$ than long-finned pilot whales Globicephala melas and lower $\delta^{13} \mathrm{C}$ than Risso's

22 dolphins Grampus griseus (Fig. 3) (Praca et al. 2011, Pinzone et al. 2015). Given the expected

23 diet to skin discrimination factor in odontocetes (estimated to be approximately $1.5 \%$ for $\delta^{15} \mathrm{~N}$, 
1 and $1 \%$ for $\delta^{13} \mathrm{C}$ in bottlenose dolphins Tursiops truncatus; Browning et al. 2014, Giménez et

2 al. 2016) and reported values in putative prey samples (Praca et al. 2011, Fanelli et al. 2013,

3 Navarro et al. 2013, Valls et al. 2017), our stable isotope results are broadly compatible with a

4 diet of Histioteuthidae (Fig. 3), as indicated by previous stable isotope (Praca et al. 2011) and

5 stomach content analysis (Roberts 2003, Garibaldi \& Podestà 2014, Foskolos et al. 2020). The

6 comparison of a small number of stomachs from stranded males and females in the Eastern basin

7 suggested that both sexes were mainly targeting the cephalopod Histioteuthis bonnellii, but

8 female diet was characterised by a higher proportion of the smaller congener H. reversa, which

9 was also more prevalent in the diet of calves (I. Foskolos, personal communication). These

10 observations are in agreement with the isotopic differences between the sexes we detected.

11 However, uncertainty remains on the species or sizes targeted by male and female sperm whales

12 in the Mediterranean and on the ecology of their prey. Further stomach content data and putative

13 prey sampling are required to elucidate the diet of the two sexes in this region.

14 A series of mechanisms could act, either alone or in concert, to produce the observed sex 15 differences in diet and the resulting fine-scale habitat segregation (Ruckstuhl 2007, Wearmouth $16 \&$ Sims 2008). Males, being larger, could have different energy requirements and diving 17 abilities, which would allow them to target larger, deeper prey. Social affinities (that is, the tendency to associate with members of the same sex) are also possible in this highly social 19 species (Whitehead 2003, Wearmouth \& Sims 2008). Alternatively, social units might be 20 responding to reproductive requirements, such as the need to care for young individuals with 21 limited diving abilities, or to feed more intensely to cover the costs of gestation and lactation. As 22 a result, females might also be more efficient at extracting resources, outcompeting males by 23 scramble competition and forcing them to target different prey (Whitehead 2003, Breed et al. 
1 2006). Sexual segregation would thus reduce intersexual competition when sexes occur in the

2 same region, while allowing males to access the energy they need to sustain their size (Beck et

3 al. 2007).

4 Determining whether observed differences are ancestral in the species or the result of adaptation

5 in this isolated population would require further investigating dietary patterns outside the

6 Mediterranean and a better understanding of the population's phylogenetic history (Engelhaupt

7 et al. 2009). It has been long recognised that male and female sperm whales from populations

8 inhabiting other ocean basins are sexually segregated at a large, latitudinal scale (Whitehead

9 2003). The evidence from our study, combined with existing habitat modelling results (Pirotta et

10 al. 2011, 2020), suggests that dietary differences occur even in this latitudinally restricted

11 population and that the sexes could also segregate at a much smaller scale. Segregation between

12 the sexes could act as a mechanism underpinning intraspecific resource partitioning in sperm

13 whales, which is increasingly recognised as an important ecological and evolutionary process

14 (e.g., Field et al. 2005, Svanbäck \& Bolnick 2007).

15 Our results contribute to shed further light on the poorly understood ecology of the

16 Mediterranean sperm whale population. Dietary differences may suggest that the broad sympatry

17 between the sexes in the basin, possibly resulting from the latitudinal restrictions to male

18 migration, could increase intraspecific competition for resources (Rendell \& Frantzis 2016).

19 Moreover, male and female feeding ecology might influence their movements at multiple scales

20 (e.g. between and within portions of the Mediterranean, and over the seasons), which could help

21 clarify why social units are mostly encountered in specific areas, and specific habitats within

22 those areas (Frantzis et al. 2014, Pace et al. 2018, Pirotta et al. 2020). Finally, understanding the

23 species' ecology will help explore some of the differences in social behaviour observed in the 
1 basin (e.g. the smaller size of social units compared to oceanic populations; Rendell \& Frantzis

2 2016).

3 Dietary analysis should be repeated to expand the small sample size and investigate whether

4 detected differences are consistent between seasons and years (Guerra et al. 2020). Comparison

5 of male and female diving behaviour (particularly in terms of targeted depth layer) and feeding

6 success would also contribute to further clarify the mechanisms underlying these sexual

7 differences, although this analysis would have to account for any diurnal vertical migration of

8 the prey. The GEE analysis suggested that any lack of independence among samples from the

9 same group did not affect the significance of the effect of sex, but more samples could be used to

10 assess group-specific dietary preferences (Marcoux et al. 2007). The sampling of several males

11 in clusters, which were considered group encounters in the field, suggests that the social structure

12 of this population, and the resulting isotopic differences, might vary significantly from those in

13 other oceans, where considerable variation has already been documented (Whitehead et al.

14 2012). Further confirmatory sampling would also help quantify any geographic variation in diet

15 within the sexes (for example, see potential differences among females sampled at different

16 latitudes in Fig. 1) or within individuals (Guerra et al. 2020), as well as sex differences in niche

17 width, possibly related to differences in size and metabolism, termed the forage selection

18 hypothesis (Ruckstuhl 2007, Main 2008). Finally, we observed that one small (possibly younger)

19 male showed similar isotopic values to females: this is consistent with the notion of ontogenetic

20 shifts in sperm whale diet suggested by analysis of stable isotopes in teeth (Mendes et al. 2007b,

21 Borrell et al. 2013), and with previous findings of similarities in the diet of females and

22 immatures (e.g., Ruiz-Cooley et al. 2004), but again more independent samples are needed for

23 confirmation. 
1 Aside from fundamental insights into the ecology of this isolated population and the evolutionary

2 forces that underpin the species' complex social structure, understanding patterns of sexual

3 segregation will be important for quantifying sex-specific rates of interactions with human

4 activities (Wearmouth \& Sims 2008). Collisions with vessels, entanglement in fishing gear, and

5 exposure to pollutants (including noise) are some of the threats sperm whales face in the

6 Mediterranean Sea (Rendell \& Frantzis 2016). The differences in feeding ecology between males

7 and females we have highlighted here could reflect contrasting habitat use or diving behaviour,

8 which, in turn, would imply a different susceptibility of the sexes to these threats. For example,

9 different diving depths or frequency may affect the time spent near the surface, where

10 individuals are vulnerable to vessel strikes (Laist et al. 2001). Moreover, the preferential use of

11 certain habitats may modulate the amount of traffic, noise, fishing gear or plastic debris an

12 individual is exposed to (e.g., De Stephanis et al. 2013, Erbe et al. 2014, Cózar et al. 2015, Breen

13 et al. 2016, Abrahms et al. 2019). Depending on a species' life history, the demographic rates of

14 one or both sexes may primarily influence population dynamics (Caswell 2001, Gerber \& White

15 2014). Therefore, if sexual segregation were confirmed in Mediterranean sperm whales, the

16 successful conservation of this 'Endangered' population would require differential strategies

17 targeting specific threats to either females or males in distinct areas.

Acknowledgements

20 This work was supported by the National Geographic Society [grant number EC-53116R-18].

21 We are also grateful to WWF, the Swiss Cetacean Society and to all field volunteers. Thanks to

22 Pilar Rubio, Pilar Teixidor and Asunción Borrell of the University of Barcelona and the Centres

23 Científics i Teconlògics (CCiTUB) for their collaboration in stable isotope analysis. We thank 
1 Ilias Foskolos, Emer Rogan, and Shane Gero for advice during the development of this study,

2 and UCC for providing desk space to EP.

3

\section{$4 \quad$ Ethics statement}

5 Data collection was carried out in compliance with Spanish regulations and under a permit to

6 JMB from the Directorate-General for Sustainability of the Coast and the Sea of the Ministry for

7 the Ecological Transition.

8 This study was approved by the Animal Welfare and Ethics Committee (AWEC) of the

9 University of St Andrews (UK).

10

\section{Data availability}

12 Data will be made publicly available on the Open Science Framework repository upon

13 acceptance.

14

15 Authors' contributions

16 EP and LR conceived the study, with contributions from all other co-authors; JMB, MC, EP and

17 LR collected the data; MV led the stable isotope analysis and interpretation of the results; ED

18 carried out the genetic sex determination; EP carried out the statistical analyses and drafted the

19 manuscript. All authors critically revised the manuscript, gave final approval for publication and

20 agree to be held accountable for the work performed therein. 


\section{LITERATURE CITED}

3 Abrahms B, Welch H, Brodie S, Jacox MG, Becker EA, Bograd SJ, Irvine LM, Palacios DM, Mate BR, Hazen EL (2019) Dynamic ensemble models to predict distributions and anthropogenic risk exposure for highly mobile species. Divers Distrib:1-12.

Alexander A, Steel D, Hoekzema K, Mesnick SL, Engelhaupt D, Kerr I, Payne R, Baker CS (2016) What influences the worldwide genetic structure of sperm whales (Physeter macrocephalus)? Mol Ecol 25:2754-2772.

Bailleul F, Authier M, Ducatez S, Roquet F, Cherel Y, Guinet C (2010) Looking at the unseen: combining animal bio-logging and stable isotopes to reveal a shift in the ecological niche of a deep diving predator. Ecography (Cop) 33:709-719.

Baum JK, Worm B (2009) Cascading top-down effects of changing oceanic predator abundances. J Anim Ecol 78:699-714.

Beck CA, Iverson SJ, Bowen WD, Blanchard W (2007) Sex differences in grey seal diet reflect seasonal variation in foraging behaviour and reproductive expenditure: Evidence from quantitative fatty acid signature analysis. J Anim Ecol 76:490-502.

Best P (1999) Food and feeding of sperm whales Physeter macrocephalus off the west coast of South Africa. South African J Mar Sci 21:393-413.

Bligh E, Dyer W (1959) A rapid method of total lipid extraction and purification. Can J Biochem Physiol 37:911-917.

Borrell A, Vacca AV, Pinela AM, Kinze C, Lockyer CH, Vighi M, Aguilar A (2013) Stable 
isotopes provide insight into population structure and segregation in eastern north atlantic sperm whales. PLoS One 8:1-10.

Bowen WD (1997) Role of marine mammals in aquatic ecosystems. Mar Ecol Prog Ser 158:267-274.

Breed GA, Bowen WD, McMillan JI, Leonard ML (2006) Sexual segregation of seasonal foraging habitats in a non-migratory marine mammal. Proc R Soc B Biol Sci 273:23192326.

Breen P, Brown S, Reid D, Rogan E (2016) Modelling cetacean distribution and mapping overlap with fisheries in the northeast Atlantic. Ocean Coast Manag 134:140-149.

Browning NE, Dold C, I-Fan J, Worthy GAJ (2014) Isotope turnover rates and diet-tissue discrimination in skin of ex situ bottlenose dolphins (Tursiops truncatus). J Exp Biol 217:214-221.

Carpinelli E, Gauffier P, Verborgh P, Airoldi S, David L, Di-Méglio N, Cañadas A, Frantzis A, Rendell L, Lewis T, Mussi B, Pace DS, De Stephanis R (2014) Assessing sperm whale (Physeter macrocephalus) movements within the western Mediterranean Sea through photo-identification. Aquat Conserv Mar Freshw Ecosyst 24:23-30.

Caswell H (2001) Matrix population models. John Wiley \& Sons, Ltd.

Clarke MR, Martins HR, Pascoe PL (1993) The diet of sperm whales (Physeter macrocephalus Linnaeus 1758) off the Azores. Philos Trans R Soc B Biol Sci 339:67-82.

Clarke R, Paliza 0., Aguayo A (1988) Sperm whales of the southeast Pacific, Part IV: Fatness, food and feeding. In: Investigations on Cetacea. Volume XXI. Pilleri G (ed) Privately 
published by G. Pilleri, Berne., p 53-195

2 Cózar A, Sanz-Martín M, Martí E, González-Gordillo JI, Ubeda B, Á.gálvez J, Irigoien X,

3 Duarte CM (2015) Plastic accumulation in the mediterranean sea. PLoS One 10:1-12.

4 Cranford TW (1999) The sperm whale's nose: Sexual selection on a grand scale? Mar Mammal $5 \quad$ Sci 15:1133-1157.

Drouot-Dulau V, Gannier A (2007) Movements of sperm whale in the western Mediterranean sea: preliminary photo-identification results. J Mar Biol Assoc United Kingdom 87:195200.

Drouot V, Bérubé M, Gannier A, Goold JC, Reid RJ, Palsbøll PJ (2004a) A note on genetic isolation of Mediterranean sperm whales (Physeter macrocephalus) suggested by mitochondrial DNA. J Cetacean Res Manag 6:29-32.

Drouot V, Gannier A, Goold JC (2004b) Diving and feeding behaviour of sperm whales (Physeter macrocephalus) in the Northwestern Mediterranean Sea. Aquat Mamm 30:419426.

Engelhaupt D, Rus Hoelzel A, Nicholson C, Frantzis A, Mesnick S, Gero S, Whitehead H, Rendell L, Miller P, De Stefanis R, CaÑadas A, Airoldi S, Mignucci-Giannoni AA (2009) Female philopatry in coastal basins and male dispersion across the North Atlantic in a highly mobile marine species, the sperm whale (Physeter macrocephalus). Mol Ecol 18:4193-4205.

Erbe C, Williams R, Sandilands D, Ashe E (2014) Identifying modeled ship noise hotspots for marine mammals of Canada's Pacific region. PLoS One 9:1-10. 
1 Evans K, Hindell MA (2004) The diet of sperm whales (Physeter macrocephalus) in southern 2 Australian waters. ICES J Mar Sci 61:1313-1329.

3 Fanelli E, Papiol V, Cartes JE, Rumolo P, López-Pérez C (2013) Trophic webs of deep-sea

4

21 Gavrilchuk K, Lesage V, Ramp C, Sears R, Bérubé M, Bearhop S, Beauplet G (2014) Trophic 
niche partitioning among sympatric baleen whale species following the collapse of groundfish stocks in the Northwest Atlantic. Mar Ecol Prog Ser 497:285-301.

Gerber LR, White ER (2014) Two-sex matrix models in assessing population viability: When do male dynamics matter? J Appl Ecol 51:270-278.

Giménez J, Ramírez F, Almunia J, G. Forero M, de Stephanis R (2016) From the pool to the sea: Applicable isotope turnover rates and diet to skin discrimination factors for bottlenose dolphins (Tursiops truncatus). J Exp Mar Bio Ecol 475:54-61.

Giménez J, Ramírez F, Forero MG, Almunia J, Stephanis R De, Navarro J (2017) Lipid effects on isotopic values in bottlenose dolphins (Tursiops truncatus) and their prey with implications for diet assessment. Mar Biol 164:122.

Graham BS, Koch PL, Newsome SD, Mcmahon KW, Aurioles D (2010) Using isoscapes to trace the movements and foraging behavior of top predators in oceanic ecosystems. In: Understanding movement, pattern, and process on Earth through isotope mapping. West JB, Bowen GJ, Dawson TE, Tu KP (eds) Springer, p 299-318

Gregr EJ, Trites AW (2011) Predictions of critical habitat for five whale species in the waters of coastal British Columbia. Can J Fish Aquat Sci 58:1265-1285.

Guerra M, Wing L, Dawson S, Rayment W (2020) Stable isotope analyses reveal seasonal and inter-individual variation in the foraging ecology of sperm whales. Mar Ecol Prog Ser 638:207-219.

Hardin JW, Hilbe JM (2003) Generalized estimating equations, 3rd ed. Chapman \& Hall/CRC Press, London. 
1 Hooker SK, Iverson SJ, Ostrom P, Smith SC (2001) Diet of northern bottlenose whales inferred

2 from fatty-acid and stable-isotope analyses of biopsy samples. Can J Zool 79:1442-1454.

3 Jackson AL, Inger R, Parnell AC, Bearhop S (2011) Comparing isotopic niche widths among

$4 \quad$ and within communities: SIBER - Stable Isotope Bayesian Ellipses in R. J Anim Ecol $5 \quad 80: 595-602$.

6 Jones EL, Rendell L, Pirotta E, Long JA (2016) Novel application of a quantitative spatial 7 comparison tool to species distribution data. Ecol Indic 70:67-76.

8 Kawakami T (1980) A review of sperm whale food. Sci Reports Whales Res Inst 32:199-218.

9 Kernaléguen L, Arnould JPY, Guinet C, Cazelles B, Richard P, Cherel Y (2016) Early-life 10 sexual segregation: ontogeny of isotopic niche differentiation in the Antarctic fur seal. Sci $11 \quad$ Rep 6:33211.

12 Laist DW, Knowlton A, Mead G, Collet A, Podesta M (2001) Collisions between ships and $13 \quad$ whales. Mar Mammal Sci 17:35-75.

14 Lesage V, Hammill MO, Kovacs KM (2001) Marine mammals and the community structure of 15 the Estuary and Gulf of St Lawrence, Canada: evidence from stable isotope analysis. Mar 16 Ecol Prog Ser 210:203-221.

17 Lesage V, Morin Y, Rioux È, Pomerleau C, Ferguson SH, Pelletier É (2010) Stable isotopes and 18 trace elements as indicators of diet and habitat use in cetaceans: Predicting errors related to 19 20 21

Logan JM, Lutcavage ME (2008) A comparison of carbon and nitrogen stable isotope ratios of fish tissues following lipid extractions with non-polar and traditional chloroform/methanol 
solvent systems. Rapid Commun Mass Spectrom 22:1081-1086.

Main MB (2008) Reconciling competing ecological explanations for sexual segregation in ungulates. Ecology 89:693-704.

Marcoux M, McMeans BC, Fisk AT, Ferguson SH (2012) Composition and temporal variation in the diet of beluga whales, derived from stable isotopes. Mar Ecol Prog Ser 471:283-291.

Marcoux M, Whitehead H, Rendell L (2007) Sperm whale feeding variation by location, year, social group and clan: Evidence from stable isotopes. Mar Ecol Prog Ser 333:309-314.

Mazzariol S, Guardo G Di, Petrella A, Marsili L, Fossi CM, Leonzio C, Zizzo N, Vizzini S, Gaspari S, Pavan G, Podestà M, Garibaldi F, Ferrante M, Copat C, Traversa D, Marcer F, Airoldi S, Frantzis A, de Beraldo Quirós Y, Cozzi B, Fernández A (2011) Sometimes sperm whales (Physeter macrocephalus) cannot find their way back to the high seas: A multidisciplinary study on a mass stranding. PLoS One 6.

Mendes S, Newton J, Reid RJ, Frantzis A, Pierce GJ (2007a) Stable isotope profiles in sperm whale teeth: Variations between areas and sexes. J Mar Biol Assoc United Kingdom 87:621-627.

Mendes S, Newton J, Reid RJ, Zuur AF, Pierce GJ (2007b) Stable carbon and nitrogen isotope ratio profiling of sperm whale teeth reveals ontogenetic movements and trophic ecology. Oecologia 151:605-615.

Navarro J, Coll M, Somes CJ, Olson RJ (2013) Trophic niche of squids: Insights from isotopic data in marine systems worldwide. Deep Res Part II Top Stud Oceanogr 95:93-102.

Newsome SD, Clementz MT, Koch PL (2010) Using stable isotope biogeochemistry to study 
marine mammal ecology. Mar Mammal Sci 26:509-572.

Nielsen JM, Clare EL, Hayden B, Brett MT, Kratina P (2018) Diet tracing in ecology: Method comparison and selection. Methods Ecol Evol 9:278-291.

Pace DS, Arcangeli A, Mussi B, Vivaldi C, Ledon C, Lagorio S, Giacomini G, Pavan G, Ardizzone G (2018) Habitat suitability modeling in different sperm whale social groups. J Wildl Manage 82:1062-1073.

Pinzone M, Budzinski H, Tasciotti A, Ody D, Lepoint G, Schnitzler J, Scholl G, Thomé JP, Tapie N, Eppe G, Das K (2015) POPs in free-ranging pilot whales, sperm whales and fin whales from the Mediterranean Sea: Influence of biological and ecological factors. Environ Res 142:185-196.

Pirotta E, Brotons JM, Cerdà M, Bakkers S, Rendell LE (2020) Multi-scale analysis reveals changing distribution patterns and the influence of social structure on the habitat use of an endangered marine predator, the sperm whale Physeter macrocephalus in the Western Mediterranean Sea. Deep Sea Res Part I Oceanogr Res Pap 155:103169.

Pirotta E, Matthiopoulos J, MacKenzie M, Scott-Hayward L, Rendell L (2011) Modelling sperm whale habitat preference: a novel approach combining transect and follow data. Mar Ecol Prog Ser 436:257-272.

Post DM (2002) Using stable isotopes to estimate trophic position: models, methods, and assumptions. Ecology 83:703-718.

Praca E, Laran S, Lepoint G, Thomé JP, Quetglas A, Belcari P, Sartor P, Dhermain F, Ody D, Tapie N, Budzinski H, Das K (2011) Toothed whales in the northwestern Mediterranean: 
Insight into their feeding ecology using chemical tracers. Mar Pollut Bull 62:1058-1065.

R Core Team (2019) R: A language and environment for statistical computing. R Foundation for Statistical Computing, Vienna, Austria. URL http://www.R-project.org/.

Rendell L, Frantzis A (2016) Mediterranean sperm whales, Physeter macrocephalus: The precarious state of a lost tribe. Adv Mar Biol 75:37-74.

Rendell L, Simião S, Brotons JM, Airoldi S, Fasano D, Gannier A (2014) Abundance and movements of sperm whales in the western Mediterranean basin. Aquat Conserv Mar

Roberts SM (2003) Examination of the stomach contents from a Mediterranean sperm whale found south of Crete, Greece. J Mar Biol Assoc United Kingdom 83:667-670.

Rosel PE (2003) PCR-based sex determination in Odontocete cetaceans. Conserv Genet 4:647649.

Ruiz-Cooley RI, Gendron D, Aguíñiga S, Mesnick S, Carriquiry JD (2004) Trophic relationships

Ruckstuhl KE (2007) Sexual segregation in vertebrates: Proximate and ultimate causes. Integr Comp Biol 47:245-257.

16

17

$$
\text { between sperm whales and jumbo squid using stable isotopes of } \mathrm{C} \text { and N. Mar Ecol Prog }
$$
Ser 277:275-283.

Ryan C, McHugh B, Trueman CN, Harrod C, Berrow SD, O’Connor I (2012) Accounting for the

9
effects of lipids in stable isotope ( $\delta 13 \mathrm{C}$ and $\delta 15 \mathrm{~N}$ values) analysis of skin and blubber of balaenopterid whales. Rapid Commun Mass Spectrom 26:2745-2754.

21 Santos MB, Pierce GJ, Boyle PR, Reid RJ, Ross HM, Patterson IAP, Kinze CC, Tougaard S, 
Lick R, Piatkowski U, Hernández-García V (1999) Stomach contents of sperm whales Physeter macrocephalus stranded in the North Sea 1990-1996. Mar Ecol Prog Ser 183:281294.

Smith KJ, Trueman CN, France CAM, Peterson MJ (2020) Evaluation of two lipid removal methods for stable carbon and nitrogen isotope analysis in whale tissue. Rapid Commun Mass Spectrom In press.

De Stephanis R, Giménez J, Carpinelli E, Gutierrez-Exposito C, Cañadas A (2013) As main meal for sperm whales: Plastics debris. Mar Pollut Bull 69:206-214.

Svanbäck R, Bolnick DI (2007) Intraspecific competition drives increased resource use diversity within a natural population. Proc R Soc B Biol Sci 274:839-844.

Teloni V, Johnson MP, Miller PJO, Madsen PT (2008) Shallow food for deep divers: Dynamic foraging behavior of male sperm whales in a high latitude habitat. J Exp Mar Bio Ecol 354:119-131.

Tucker S, Bowen WD, Iverson SJ (2007) Dimensions of diet segregation in grey seals Halichoerus grypus revealed through stable isotopes of carbon $(\delta 13 \mathrm{C})$ and nitrogen $(\delta 15 \mathrm{~N})$. Mar Ecol Prog Ser 339:271-282.

Valls M, Rueda L, Quetglas A (2017) Feeding strategies and resource partitioning among elasmobranchs and cephalopods in Mediterranean deep-sea ecosystems. Deep Res Part I Oceanogr Res Pap 128:28-41.

Wearmouth VJ, Sims DW (2008) Sexual segregation in marine fish, reptiles, birds and mammals: Behaviour patterns, mechanisms and conservation implications. Adv Mar Biol 
2 Whitehead H (2003) Sperm Whales. Social evolution in the ocean. University of Chicago Press,

3 Chicago.

4 Whitehead H, Antunes R, Gero S, Wong SNP, Engelhaupt D, Rendell L (2012) Multilevel

5 societies of female sperm whales (Physeter macrocephalus) in the Atlantic and Pacific: why

$6 \quad$ are they so different? Int J Primatol 33:1142-1164.

7 Williams TM, Estes JA, Doak DF, Springer AM (2004) Killer appetites: Assessing the role of 8 predators in ecological communities. Ecology 85:3373-3384. 

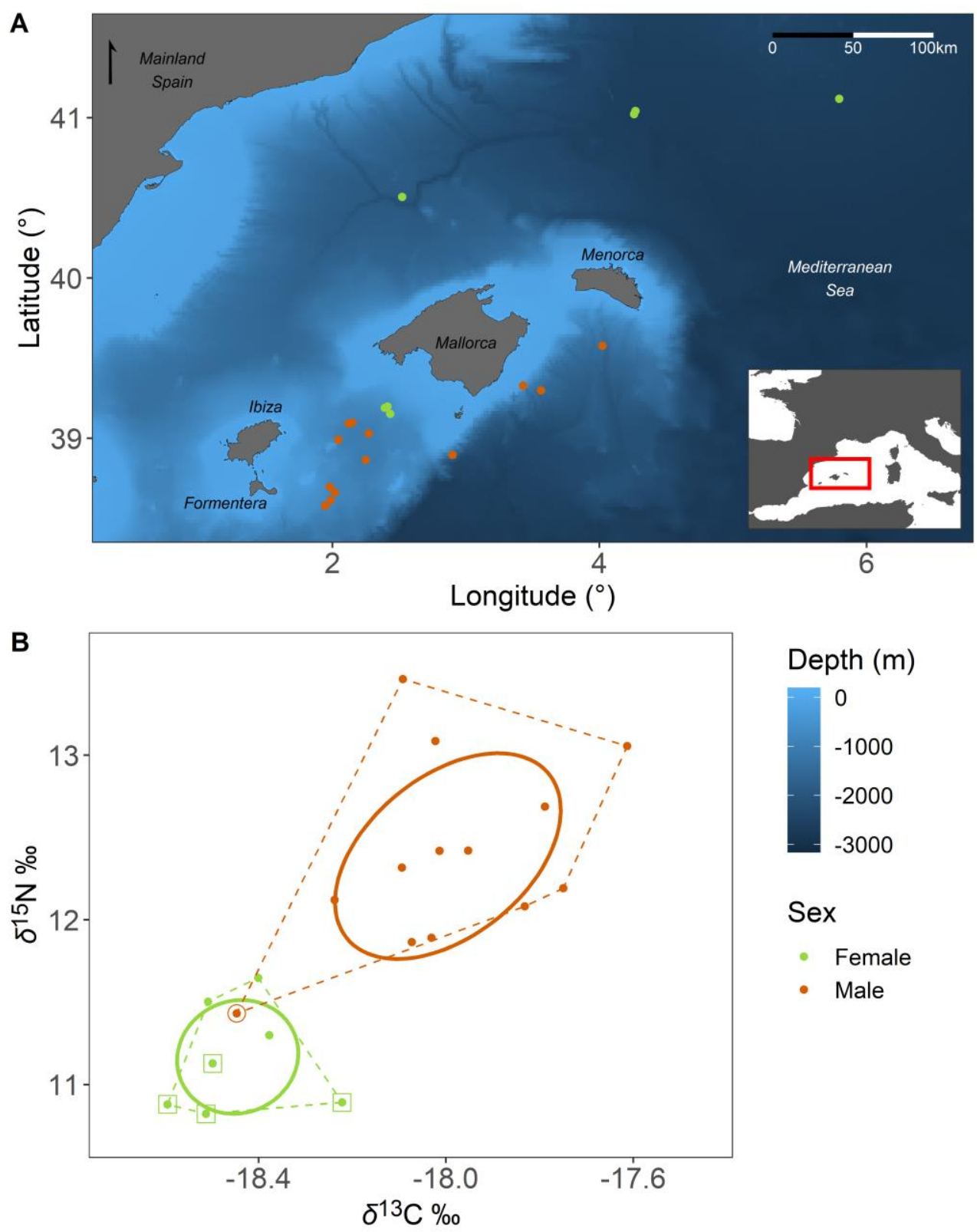

Sex

- Female

- Male

3 Figure 1. (A) Locations of sperm whale biopsy sample collection, coloured by sex, and (B) $\delta^{13} \mathrm{C}$

4 and $\delta^{15} \mathrm{~N}$ values in skin samples, with solid lines representing standard ellipses corrected for

5 sample size $\left(\mathrm{SEA}_{\mathrm{C}}\right)$ and dashed lines representing convex hull areas, coloured by sex. Sample

6 comprises 7 females and 13 males. The observation corresponding to the small male is circled,

7 while females sampled at latitudes $>40^{\circ}$ are identified by squares. 


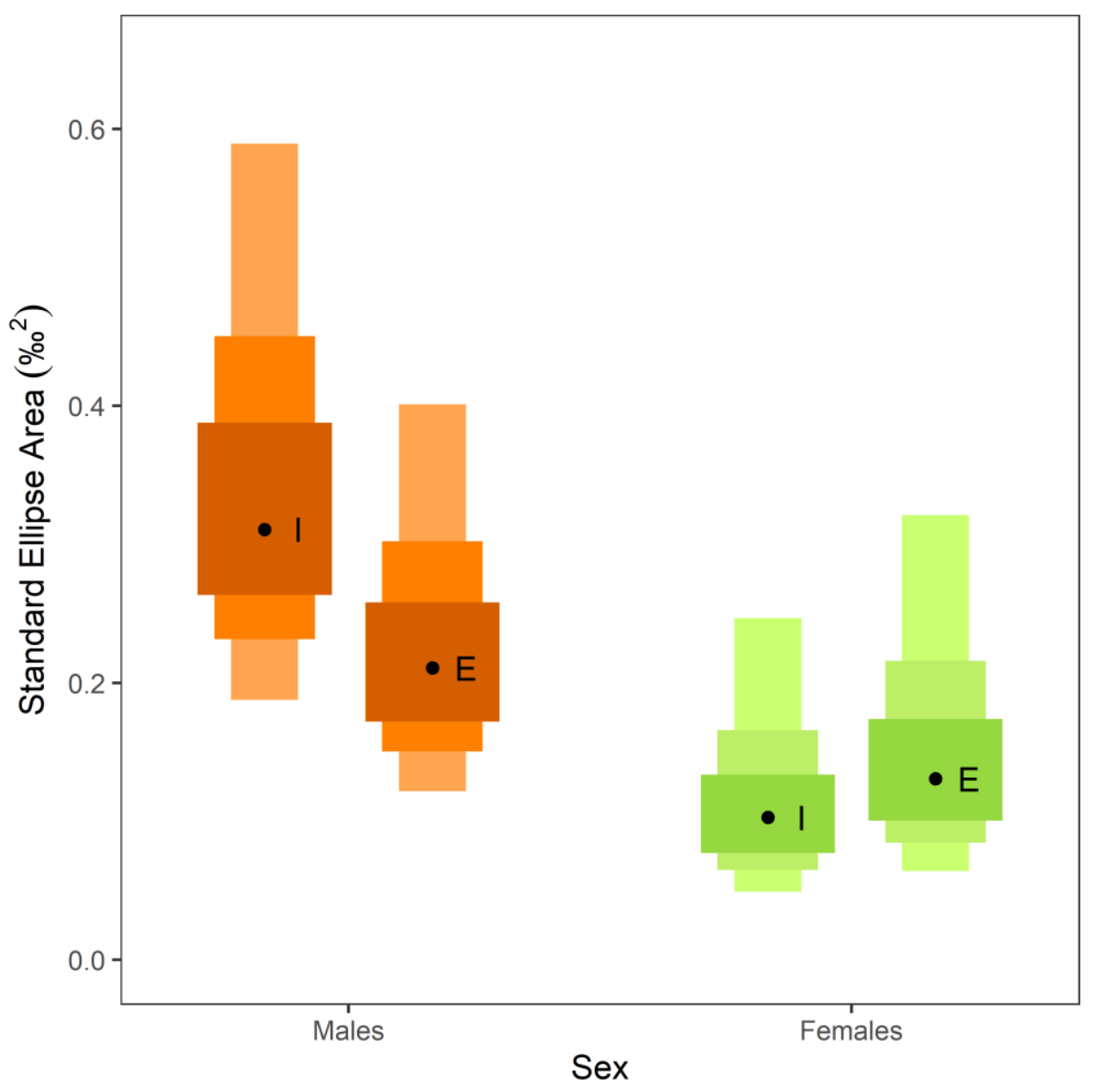

2 Figure 2. Posterior distribution of standard ellipse areas $\left(\% 0^{2}\right.$, representing estimated niche

3 widths) for males and females from the Bayesian model in SIBER, including (I) or excluding (E)

4 the small male with female-like isotope values. Therefore, males in our sample show larger niche

5 width, but this is somewhat dependent on the inclusion of the smaller sub-adult male. Black dots

6 represent the posterior modes, while the shaded boxes indicate the 50,75 and $95 \%$ credible

7 intervals (darker to lighter colours). 


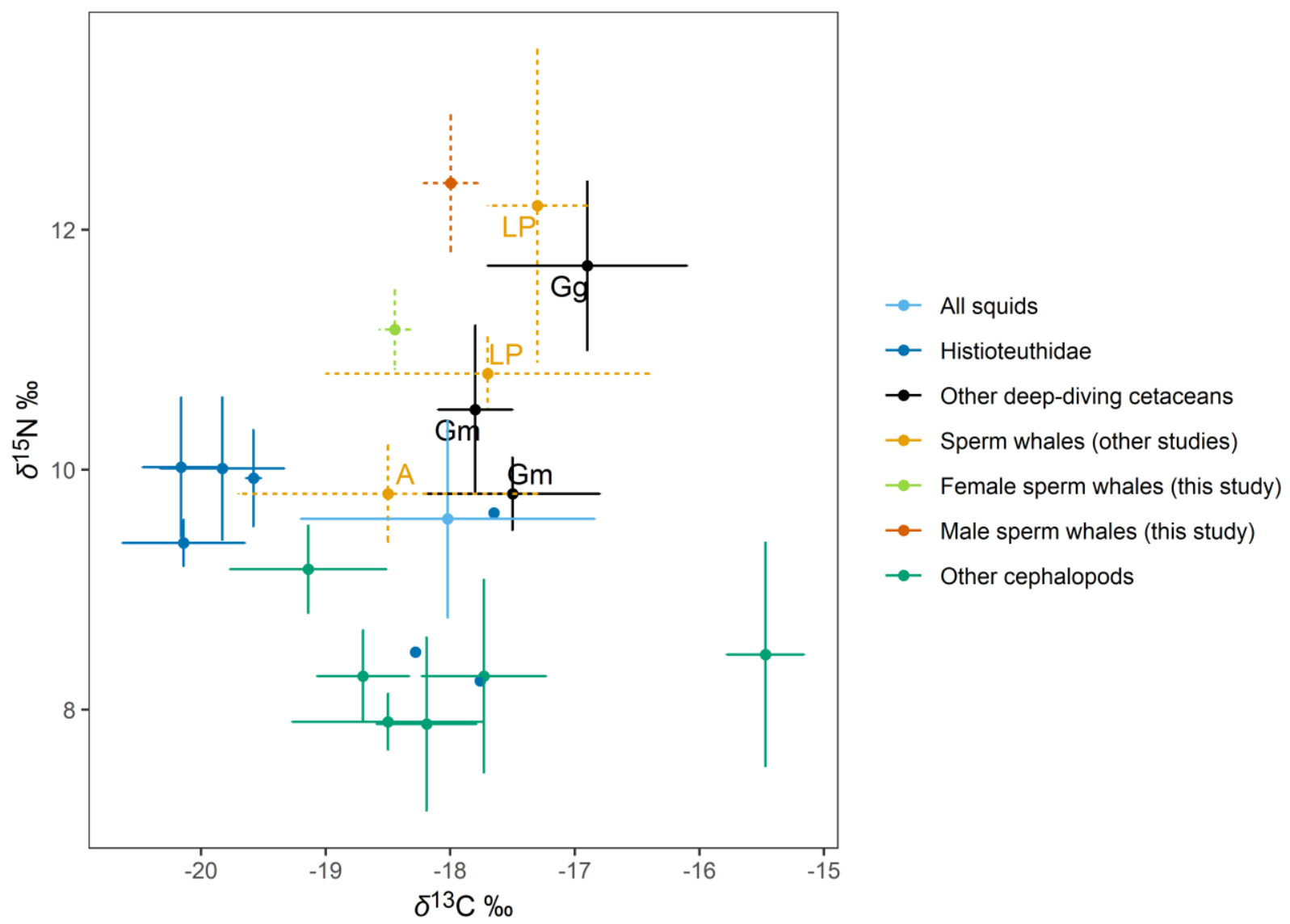

2 Figure 3. Values of $\delta^{13} \mathrm{C}$ and $\delta^{15} \mathrm{~N}$ (mean and standard deviations) in samples of Mediterranean 3 sperm whales (dashed lines), other deep-diving odontocetes, and putative prey (solid lines). Sperm

4 whale samples include males and females from this study, individuals stranded along the Adriatic 5 coast (A; Mazzariol et al. 2011), and individuals sampled in the Liguro-Provençal basin (LP; Praca 6 et al. 2011, Pinzone et al. 2015). Other deep-diving odontocetes include long-finned pilot whales 7 Globicephala melas (Gm) and Risso’s dolphins Grampus griseus (Gg) (Praca et al. 2011, Pinzone 8 et al. 2015). Putative prey include Histioteuthidae (Histioteuthis reversa and Histioteuthis 9 bonnellii; Praca et al. 2011, Fanelli et al. 2013, Valls et al. 2017), other cephalopods (other 10 Teuthoidea, Octopoda, Sepioidea; Praca et al. 2011, Fanelli et al. 2013, Valls et al. 2017) and all 11 squids (Navarro et al. 2013). Isotopic values in prey were not corrected by the discrimination 12 factors. 